\title{
Kadar Lemak, Indeks Kuning Telur, dan Susut Bobot Telur Itik setelah Pencucian Air dan Perendaman Ekstrak Daun Jambu Biji (Psidium guajava)
}

\section{Fat Levels, Egg Yolk Index, and Weight Loss of Duck Eggs after Water Washing and Soaking Guava Leaf Extract (Psidium guajava)}

\author{
Rahita Dayurani ${ }^{*}$, S. M. Mardiati ${ }^{2}$, M. Anwar Djaelani ${ }^{2}$ \\ ${ }^{1}$ Mahasiswa Program Studi Biologi, Departemen Biologi, Fakultas Sains dan Matemetika, \\ Universitas Diponegoro \\ ${ }^{2}$ Departemen Biologi, Fakultas Sains dan Matemetika, Universitas Diponegoro \\ Jl. Prof. Soedarto, SH Tembalang Semarang \\ *Email : rahitadayu@gmail.com
}

Diterima 29 September 2018 / Disetujui 28 Januari 2019

\begin{abstract}
ABSTRAK
Penelitian ini menganalisis pengaruh pencucian dan perendaman ekstrak daun jambu biji (Psidium guajava) terhadap kadar lemak telur, indeks kuning telur (IKT) dan susut bobot telur itik setelah disimpan pada suhu ruang dengan lama penyimpanan berbeda Penelitian ini menggunakan rancangan acak lengkap. Digunakan telur sebanyak 45 butir yang diambil pada satu hari setelah diovulasikan. Telur dibagi dalam 9 perlakuan dan 5 kali ulangan. Kontrol, Telur dicuci, direndam ekstrak daun jambu biji, disimpan 14 hari, Telur dicuci, direndam ekstrak daun jambu biji, disimpan 28 hari. Telur dicuci, disimpan 14 hari, Telur dicuci, disimpan 28 hari. Telur direndam ekstrak daun jambu biji, disimpan 14 hari. Telur direndam ekstrak daun jambu biji, disimpan 28 hari. Telur disimpan 14 hari. dan Telur disimpan 28 hari.. Variabel pada penelitian ini adalah kadar lemak, IKT dan susut bobot. Data dianalisis menggunakan ANOVA Simpulan i penelitian ini perendaman telur dalam ekstrak daun jambu biji dengan kadar tanin 3,9\% tidak efektif mempertahankan kualitas telur yang disimpan lebih dari 14 hari.
\end{abstract}

Kata kunci: disimpan, suhu, tanin

\section{ABSTRACT}

This study was to analyze the effects of duck eggs treatments and determine the fat content, yolk indeks and egg weight loss after washed with water and soaked in guava leaves extract were stored at room temperature. This study used 45 duck eggs which divided into 9 treatments and 5 repetitions. Control, (eggs day 1), Eggs washed with water, eggs soaked in the extract of guava leaves and stored for 14 days. (Eggs washed with water, eggs soaked in the extract of guava leaves, and stored for 28 days. Eggs washed with water, stored for 14 days. Eggs washed with water, stored for 28 days. Eggs soaked in the extract of guava leaves, stored 14 days, Eggs soaked in the extract guava leaves, stored 28 days. Eggs stored 14 days. and Eggs stored 28 days. Variable observed were fat content, yolk index and egg weight loss. The data was analyzed with ANOVA test. The conclution from this study was the duck eggs were washed and soaked in guava leaves extract with $3.9 \%$ tannin content was not effective to preserve the egg quality that stored more than 14 days.

Keywords: Storaged, temperature, tanin

\section{PENDAHULUAN}

Telur merupakan salah satu bahan makanan yang mengandung zat gizi lengkap antara lain protein, lemak, vitamin, dan mineral. Telur segar mempunyai daya simpan yang pendek sekitar 10-14 hari pada suhu ruang, setelah waktu tersebut telur mengalami kearah kerusakan seperti terjadinya penguapan kadar air melalui pori yang berakibat berkurangnya berat telur, perubahan komposisi kimia dan terjadinya pengenceran isi telur (Cornelia dkk., 2014).

Telur itik merupakan salah satu jenis telur 
yang banyak dikonsumsi oleh masyarakat Indonesia (Ketaren, 2007). Umumnya peternak itik memelihara itik dalam jumlah kecil sehingga kemungkinan dalam pendistribusian telur perlu waktu untuk dikumpulkan. Winarno dan Koswara (2002) menyatakan bahwa mutu telur itik dapat mengalami penurunan selama penyimpanan telur, baik oleh proses fisiologi maupun oleh bakteri pembusuk. Proses fisiologi berlangsung lebih cepat pada penyimpanan suhu ruang.

Penentuan kualitas telur secara internal dilihat dari bagian dalam telur yaitu dengan melihat ruang udara, kondisi kuning telur dengan mengukur Indeks Kuning Telur (IKT), dan kondisi putih telur dengan melihat daya buih, mengukur Indeks Putih Telur (IPT) serta Haugh unit (HU). Susut bobot telur, keadaan kuning telur, keadaan putih telur, serta tingkat kebersihan kerabang telur merupakan faktor-faktor kualitas yang dapat memberikan petunjuk terhadap kesegaran telur (Saraswati, 2015). Agar kualitas telur itik tidak merosot hingga busuk, perlu dilakukan pengelolaan pasca produksi telur (Rasyaf, 2011).

Perlakuan yang diberikan pada telur segar akan mempengaruhi kualitas telur tersebut, misalnya pembersihan kerabang telur (Fibrianti dkk., 2012). Sebagian besar lemak telur terdapat pada kuning telur. Kuning telur mengandung lemak sebesar 35\% (Winarno dan Koswara, 2002). Kerusakan telur diikuti dengan munculnya bau karena terjadi dekomposisi lemak, protein, dan karbohidrat (Yuwanta, 2010). Prinsip penyimpanan telur adalah mencegah evaporasi air, keluarnya $\mathrm{CO} 2$ dari dalam isi telur, dan mencegah masuknya mikroba ke dalam telur selama penyimpanan. Pengawetan telur segar dapat dilakukan dengan menutup pori kulit telur atau mengatur kelembaban dan kecepatan aliran udara dalam ruangan penyimpanan (Koswara, 2009).

Daun jambu biji mengandung metabolit sekunder yang terdiri dari tanin, polifenolat, flavanoid, monoterpenoid, siskulterpen, alkaloid, kuinon, dan saponin (Kurniawati, 2006). Daun jambu biji merupakan salah satu jenis penyamak nabati yang sering digunakan untuk pengawetan telur. Prinsip dasar dari pengawetan menggunakan daun jambu adalah terjadinya penyamakan pada bagian luar kulit telur olah zat penyamak (tanin) yang membuat kulit telur menjadi impermeabel terhadap air dan gas, sehingga dapat mencegah keluarnya air dan gas dari dalam telur (Koswara, 2009). Penelitian ini diperlukan untuk untuk mengetahui pengaruh pencucian telur itik dengan air dan pengaruh perendaman ekstrak daun jambu biji terhadap kualitas telur itik yang ditinjau dari kadar lemak telur, Indeks Kuning Telur (IKT), dan susut bobot telur telur itik.

\section{METODE PENELITIAN}

Penelitian dilakukan di Laboratorium Biologi Struktur dan Fungsi Hewan Jurusan Biologi Fakultas Sains dan Matematika Universitas Diponegoro Semarang. Penelitian ini menggunakan metode eksperimental dengan rancangan acak lengkap (RAL). Data dianalisis menggunakan uji Anova dan uji Duncan dengan taraf signifikansi $5 \%$.

Telur yang digunakan sebanyak 45 butir, dibagi dalam 9 perlakuan dan 5 kali ulangan. P0 (Telur umur 1 hari), P1 (Telur dicuci, direndam ekstrak daun jambu biji, disimpan 14 hari), P2 (Telur dicuci, direndam ekstrak daun jambu biji, disimpan 28 hari), P3 (Telur dicuci, disimpan 14 hari), P4 (Telur dicuci, disimpan 28 hari), P5 (Telur direndam ekstrak daun jambu biji, disimpan 14 hari), P6 (Telur direndam ekstrak daun jambu biji, disimpan 28 hari), P7 (telur disimpan 14 hari), dan P8 (telur disimpan 28 hari). Variabel yang diukur pada penelitian ini adalah kadar lemak, IKT dan susut bobot.

\section{Prosedur Penelitian Pengambilan Sampel}

Telur itik diambil dari peternak itik di Pandansari Semarang. Sampel yang digunakan yaitu telur itik diovulasikan pada hari pertama. Telur dipilih yang bersih dari kotoran, dan memiliki bobot yang seragam.

\section{Pembuatan Ekstrak Daun Jambu Biji}

Daun jambu biil sebanyak $200 \mathrm{~g}$ dan 2 liter air diblender hingga menjadi larutan yang homogen. Ekstraksi daun jambu dilakukan dengan metode 
pemanasan dengan suhu $80^{\circ} \mathrm{C}$ selama 17,5 menit (Sukardi dkk., 2005; Oematan, 2015). Hasil ekstrak daun jambu biii dianalisis kandungan taninnya secara spektrofotometri. Kadar tanin pada ekstrak daun jambu biji adalah 3,9\%.

\section{Perendaman Telur}

Ekstrak daun jambu biji didinginkan sampai suhunya menjadi $30^{\circ} \mathrm{C}$. Telur direndam ke dalam ekstrak daun jambu biji sampai semua permukaan telur terendam. Perendaman dilakukan selama 30 menit (Asjayani, 2014).

\section{Penyimpanan Telur}

Telur diletakkan ke dalam egg try kemudian disimpan pada suhu ruang $\left(27-33^{\circ} \mathrm{C}\right)$ selama 14 dan 28 hari.

\section{Analisis Indeks Kuning Telur}

Perhitungan IKT dilakukan dengan cara telur dipecah secara hati-hati diatas kaca bidang datar, lalu diukur tinggi kuning telur dan diameter kuning telur dengan jangka sorong. Indeks Kuning Telur (IKT) dihitung menggunakan rumus menurut Yuwanta (2010):

IKT $=\frac{\text { Tinggi kuning telur }(\mathrm{mm})}{\text { Diameter kuning telur }(\mathrm{mm})}$

\section{Analisis Kadar Lemak Telur}

Kadar lemak telur diukur dengan metode ekstraksi Soxhlet dengan rumus menurut Bintanah dan Handarsari (2014) :

Kadar lemak $=\frac{\text { Berat lemak }}{\text { Berat sampel }} \times 100 \%$

\section{Analisis Susut Bobot Telur}

Telur ditimbang menggunakan timbangan digital untuk mendapatkan bobot telur sebelum dan sesudah penyimpanan.

Pengukuran susut bobot telur dihitung dengan rumus menurut Asjayani (2014) :

Kadar lemak $=\frac{\text { Bobot awal }- \text { bobot akhir }}{\text { Bobot awal }} \times 100 \%$

\section{HASIL DAN PEMBAHASAN}

Hasil analisis data penelitian lemak telur, IKT dan susut bobot telur itik setelah perlakuan pencucian dengan air dan perendaman ekstrak daun jambu biji (Psidium guajava) disajikan pada Tabel 1. Hasil analisis perlakuan pencucian air dan perendaman ekstrak daun jambu biji (Psidium guajava) yang disimpan pada suhu ruang dengan lama penyimpanan 14 hari dan 28 hari terhadap kadar lemak telur itik menunjukkan nilai yang berbeda nyata $(\mathrm{P}<0,05)$. Telur itik $\mathrm{P} 0$ yaitu telur yang diovulasikan hari pertama memiliki kadar lemak sebesar 14,02\%, telur itik P7 dengan perlakuan penyimpanan 14 hari memiliki kadar lemak sebesar 13,62\% dan telur itik P8 dengan perlakuan penyimpanan 28 hari memiliki kadar lemak sebesar 10,78\%. Kadar lemak perlakuan P7 tidak berbeda nyata dengan perlakuan P0, P1, P3 dan P5, namun P7 berbeda nyata dengan P2, P4, P6, dan P8. Penyimpanan telur itik P8 memiliki hasil yang tidak berbeda nyata dengan $\mathrm{P} 2$ dan $\mathrm{P} 4$, namun P8 berbeda nyata dengan perlakuan P0, P1, P3, P5, P6 dan P7.

Hasil tersebut menunjukkan bahwa penyimpanan telur itik selama 28 hari dapat menurunkan kadar lemak telur. Telur itik tanpa pencucian air dan perendaman ekstrak daun jambu biji hari pertama memiliki kadar lemak sebesar $14,02 \%$ setelah masa penyimpanan 28 hari kadar lemak telur itik menurun menjadi 10,78\%. Telur itik segar secara utuh mempunyai kadar lemak sebesar 14,30\% dan sebagian besar lemak telur terdapat pada kuning telur (Winarno dan Koswara, 2002). Air merupakan komponen terbesar dari puth telur. Puth telur kental mengandung kadar air sebesar 87,6\% (Yuwanta, 2010). Penyimpanan telur itik akan mengakibatkan perpindahan air dari putih telur ke kuning telur karena terdapat perbedaan tekanan osmotik antara putih telur dengan kuning telur. Hal ini sesuai dengan Soeparno dkk. (2011) yang menyatakan bahwa pada saat telur dioviposisikan, kuning telur memiliki tekanan osmotik 320 mOsm dan puth telur memiliki tekanan osmotik 250 mOsm. Perbedaan tekanan osmotik ini menyebabkan air berpindah dari puth telur menuju kuning telur. Proses ini menyebabkan 
penurunan elastisitas membran vitelin dan membesarnya diameter kuning telur yang dapat menyebabkan pecahnya kuning telur.

Kadar lemak P1 dengan perlakuan pencucian, perendaman dalam larutan ekstrak daun jambu biji, dan penyimpanan 14 hari memiliki hasil yang tidak berbeda nyata dengan P3, P5 dan P7. Hal ini menunjukkan bahwa perlakuan pencucian air dan perendaman ekstrak daun jambu biji tidak memberikan pengaruh nyata terhadap kadar lemak telur itik yang disimpan selama 14 hari. P1 juga menunjukkan hasil yang tidak berbeda nyata dengan P0.
Diduga sampai penyimpanan hari ke-14 belum terjadi kerusakan yang signifikan yang menyebabkan turunya kadar lemak telur. Kadar lemak telur penyimpanan 28 hari menunjukkan penurunan kadar lemak yang berbeda nyata dari penyimpanan 14 hari, dapat dilihat pada Tabel 4.1 perlakuan P1 memiliki kadar lemak yang berbeda nyata dengan perlakuan P2, P4, P6 dan P8 dengan penyimpanan 28 hari. Diduga kadar lemak telur itik pada penyimpanan 28 hari mengalami kerusakan karena adanya proses hidrolisis.

Tabel 1. Lemak Telur (LT), Indeks Kuning Telur (IKT) dan Susut Bobot Telur (SB) itik setelah perlakuan pencucian dengan air dan perendaman ekstrak daun jambu biji (Psidium guajava) yang disimpan pada suhu ruang dengan waktu penyimpanan yang berbeda

\begin{tabular}{llrrrrrrrr}
\hline & \multicolumn{1}{c}{ P0 } & P1 & P2 & P3 & P4 & P5 & P6 & P7 & \multicolumn{1}{c}{ P8 } \\
\hline LT (\%) & $14,02^{\mathrm{a}}$ & $13,96^{\mathrm{a}}$ & $11,08^{\mathrm{b}}$ & $13,82^{\mathrm{a}}$ & $10,42^{\mathrm{cd}}$ & $13,62^{\mathrm{a}}$ & $9,97^{\mathrm{d}}$ & $13,62^{\mathrm{a}}$ & $10,78^{\mathrm{bc}}$ \\
& $\pm 0,14$ & $\pm 0,26$ & $\pm 0,56$ & $\pm 0,33$ & $\pm 0,28$ & $\pm 0,33$ & $\pm 0,45$ & $\pm 0,39$ & $\pm 0,91$ \\
IKT & $0,42^{\mathrm{a}}$ & $0,34^{\mathrm{b}}$ & $0,29^{\mathrm{c}}$ & $0,32^{\mathrm{b}}$ & $0,26^{\mathrm{d}}$ & $0,34^{\mathrm{b}}$ & $0,28^{\mathrm{cd}}$ & $0,32^{\mathrm{b}}$ & $0,27^{\mathrm{cd}}$ \\
& $\pm 0,02$ & $\pm 0,01$ & $\pm 0,01$ & $\pm 0,02$ & $\pm 0,01$ & $\pm 0,01$ & $\pm 0,02$ & $\pm 0,01$ & $\pm 0,01$ \\
SB & $0,00^{\mathrm{a}}$ & $0,235^{\mathrm{b}}$ & $0,461^{\mathrm{c}}$ & $0,287^{\mathrm{b}}$ & $0520^{\mathrm{c}}$ & $0,251^{\mathrm{b}}$ & $0,463^{\mathrm{c}}$ & $0.264^{\mathrm{b}}$ & $0,516^{\mathrm{c}}$ \\
& $\pm 0,00$ & $\pm 0,15$ & $\pm 0,84$ & $\pm 0,61$ & $\pm 0,42$ & $\pm 0,20$ & $\pm 0,46$ & $\pm 0,35$ & $\pm 0,22$ \\
\hline
\end{tabular}

Keterangan: angka yang diikuti superskrip yang sama pada baris yang sama menunjukkan hasil yang tidak berbeda nyata $(\mathrm{P}>0,05)$ pada taraf signifikansi 5\%. LT: Lemak Telur, IKT Indeks Kuning Telur :, SB : Susut Bobot Telur

Alfiah dkk. (2015) menyatakan bahwa salah satu penyebab kerusakan lemak adalah adanya reaksi hidrolisis. Reaksi hidrolisis menyebabkan pemecahan lemak menjadi asamasam lemak bebas dan gliserol. Air merupakan katalis dalam proses hidrolisis lemak. Kandungan air dalam lemak akan memicu terjadinya proses hidrolisis yang mengakibatkan terbentuknya asam lemak bebas. Jika kadar air di dalam lemak tersebut tinggi, maka kemungkinan terjadinya reaksi hidrolisis akan semakin besar dan akan memicu kenaikan asam lemak bebas sebagai hasil pemecahan trigliserida.

Kadar lemak telur itik P2 dengan perlakuan pencucian, perendaman dalam larutan ekstrak daun jambu biji, dan penyimpanan 28 hari tidak berbeda nyata dengan kadar lemak dengan perlakuan $\mathrm{P} 8$, namun $\mathrm{P} 2$ berbeda nyata dengan $\mathrm{P} 0$, P1, P3, P4, P5, P6, P7. P2 memiliki kadar lemak
$11,08 \%$ berbeda nyata dengan kelompok telur P6 yang hanya diberikan perlakuan perendaman ekstrak daun jambu biji dengan kadar lemak 9,96\%. Diduga pencucian dan perendaman telur ke dalam ekstrak daun jambu biji mampu mempertahankan kadar lemak.

Perendaman telur ke dalam ekstrak daun jambu biji bertujuan untuk melapisi pori kerabang telur dengan tanin yang terdapat pada daun jambu. Penyimpanan telur sistem pencelupan atau immersion liquid dilakukan dengan mencelupkan telur ke dalam cairan dengan tujuan untuk menutup pori (Yuwanta, 2010). Tanin secara ilmiah didefinisikan sebagai senyawa polifenol yang mempunyai berat molekul tinggi dan mempunyai gugus hidroksil dan gugus karboksil sehingga dapat membentuk kompleks dengan protein dan makromolekul lainnya di bawah kondisi lingkungan tertentu 
(Danarto dkk., 2011). Sifat tanin yang larut dalam air dapat digunakan sebagai bahan penyamak telur, karena mampu melapisi pori pada kulit luar atau cangkang telur, sehingga menghambat masuknya bakteri melalui pori tersebut (Budisutiya dan Arisandi, 2006).

Kotoran unggas yang menempel pada kulit kerabang telur merupakan sumber utama pencemaran pada telur (Birowo, 2013). Ketika telur dikeluarkan dari kloaka saat oviposisi sudah terjadi kontaminasi bakteri dari saluran pencernaan yang hidup di kloaka, kemudian setelah dioviposisikan juga terjadi kontaminasi oleh bakteri yang terdapat di kandang unggas (Yuwanta, 2010). Geveke et al.(2016) yang menyatakan bahwa bakteri Salmonella enteritidis ada pada kerabang telur. Penyimpanan telur dalam jangka waktu yang lama dibutuhkan kebersihan dari kerabang telur. Pencucian telur dapat dilakukan asalkan tidak berlebihan (Saraswati, 2015).

Telur itik dengan perlakuan P3 yaitu pencucian dan penyimpanan 14 hari memiliki kadar lemak $13,82 \%$ yang tidak berbeda nyata dengan perlakuan P0, P1, P5 dan P7. Hasil juga menunjukkan $\mathrm{P} 3$ berbeda nyata dengan perlakuan P2, P4, P6, dan P8. Perlakuan P4 yaitu dengan perlakuan pencucian dan penyimpanan 28 hari memiliki hasil kadar lemak sebesar $10,42 \%$ yang tidak berbeda nyata dengan P6, P8, namun berbeda nyata dengan perlakuan P0, P1, P2, P3, P5 dan P7. Hal ini menunjukkan bahwa perlakuan pencucian telur itik tidak berpengaruh nyata terhadap kadar lemak telur yang disimpan selama 14 hari dan 28 hari karena tidak ada perbedaan nyata pada pengamatan kadar lemak telur di hari yang sama. Pencucian telur itik saja tanpa pelapisan tidak mampu untuk mempertahankan kualitas lemak telur itik karena terjadi penurunan kadar lemak selama penyimpanan 14 hari dan 28 hari.

Telur sangat mudah mengalami kerusakan.

Telur tanpa pengawetan memiliki umur yang lebih pendek daripada telur yang diawetkan. Pengawetan telur merupakan cara yang tepat untuk mencegah kerusakan, memperpanjang daya simpan selama proses transportasi dan distribusi. (Zulfatunnisa dan imam, 2015).
Penelitian yang telah dilakukan Djaelani (2017) tentang pencucian dan penyimpanan telur puyuh menunjukkan bahwa perlakuan pencucian dan penyimpanan pada telur menyebabkan penurunan kualitas telur yang ditinjau dari kenaikan $\mathrm{pH}$, penurunan indeks putih telur dan penurunan kadar protein telur. Pencucian menyebabkan pori kerabang telur terbuka akibat hilangnya selaput kutikula yang melapisi telur yang hilang karena pencucian.

Kadar lemak telur itik P5 yaitu perendaman kedalam ekstrak daun jambu biji dan penyimpanan 14 memiliki hasil yang tidak berbeda nyata dengan $\mathrm{P} 0, \mathrm{P} 1, \mathrm{P} 3$ dan $\mathrm{P} 7$, namun berbeda nyata dengan perlakuan $\mathrm{P} 2, \mathrm{P} 4, \mathrm{P} 6$, dan P8. Perlakuan P6 yaitu perendaman kedalam ekstrak daun jambu biji dan penyimpanan 28 hari memiliki hasil yang tidak berbeda nyata dengan $\mathrm{P} 4$, namun berbeda nyata dengan perlakuan $\mathrm{P} 0$, P1, P2, P3, P5, P7 dan P8. Perendaman telur itik kedalam ekstrak daun jambu biji bertujuan untuk mempertahankan kualitas telur. P5 menunjukkan hasil yang tidak berbeda nyata dengan telur tanpa perlakuan perendaman dan telur yang diberi pencucian air serta telur yang dicuci air dan direndam menggunakan ekstrak daun jambu biji. Perendaman telur kedalam ekstrak daun jambu biji tidak memiliki pengaruh nyata pada penyimpanan hari ke-14. Asjayani (2014) menyatakan bahwa proses pelapisan yang baik adalah yang memiliki laju penurunan kualitas telur yang lebih kecil dibandingkan dengan telur kontrol. Diduga kadar tanin pada penelitian ini kurang tinggi untuk mempertahankan kualitas telur itik.

Hasil analisis Indeks Kuning Telur (IKT) dengan pemberian perlakuan pencucian air dan perendaman ektrak daun jambu biji (Psidium guajava) yang disimpan pada suhu ruang pada Tabel 1. menunjukkan hasil yang berbeda nyata $(\mathrm{P}<0,05)$. Hal ini ditunjukkan dengan IKT yang menurun pada pengamatan hari ke-14 dan hari ke28. P0 memiliki rata-rata IKT sebesar 0,42. Winarno dan Koswara (2002) menyatakan bahwa indeks kuning telur segar beragam antara 0,33 dan 0,50 dengan nilai rata-rata 0,42 . P0 memiliki IKT yang berbeda nyata dengan semua perlakuan yaitu P1, P2, P3, P4, P5, P6, P7, dan P8. Indeks 
kuning telur itik yang disimpan selama 14 dan 28 hari mengalami penurunan yang berbeda nyata dari telur tanpa penyimpanan. Yuwanta (2010) menyatakan saat penyimpanan telur akan terjadi pemindahan air dari putih telur ke kuning telur. Transfer air ini sebanyak $10 \mathrm{mg} /$ hari pada temperatur $10^{\circ} \mathrm{C}$. Besarnya transfer air tergantung dari kekentalan putih telur dan temperatur. Apabila terjadi transfer air dari putih telur ke dalam kuning telur maka indeks kuning telur akan menurun, viskositasnya menurun, dan kuning telur akan mudah pecah. P7 yaitu penyimpanan telur itik selama 14 hari memiliki IKT yang berbeda nyata dengan P0, P2, P4, P6 dan P8 tetapi tidak berbeda nyata dengan perlakuan P1, P3, P5. Perlakuan P8 yaitu penyimpanan telur selama 28 hari memiliki hasil yang berbeda nyata dengan P0, P1, P3, P5, P7 namun tidak berbeda nyata dengan P2, P4, P6. Hal ini menunjukkan bahwa telur yang diberi perlakuan pencucian air dan perendaman ekstrak daun jambu biji, telur dengan perlakuan pencucian air, serta telur dengan perlakuan perendaman ekstrak daun jambu biji tidak memberikan pengaruh nyata terhadap telur itik yang disimpan selama 14 hari dan 28 hari karena tidak ada perbedaan nyata pada pengamatan hari yang sama.

Penurunan IKT pada penelitian ini dipengaruhi oleh lama penyimpanan, seperti yang dikatakan oleh Cornelia dkk. (2014) yaitu semakin bertambahnya umur telur, indeks kuning telur akan mengalami penurunan karena terjadi penambahan ukuran diameter kuning telur sebagai akibat dari perpindahan air. Saraswati (2015) menyatakan bahwa air yang tertarik dari putih telur menyebabkan kuning telur berubah. Bobot kuning telur bertambah, karena air berpindah dari putih telur ke kuning telur. Kuning telur yang tadinya cembung menjadi agak datar, karena berat jenis air yang lebih besar membuat kuning telur kehilangan daya cembung, sehingga kuning telur menjadi pipih dan kemudian pecah karena membran vitelin rusak. Kuning telur akan semakin lembek, sehingga indeks kuning telur akan menurun.

Djaelani (2017) menyatakan bahwa lama penyimpanan telur berbanding lurus dengan peningkatan $\mathrm{pH}$ telur. Semakin lama telur disimpan maka $\mathrm{pH}$ telur akan semakin meningkat. Perubahan kandungan $\mathrm{CO} 2$ dalam putih telur akan mengkibatkan perubahan $\mathrm{pH}$ puth telur menjadi basa karena telur mengalami penguapan air dan gas $\mathrm{CO} 2$. Akibat dari kenaikan $\mathrm{pH}$, puth telur menjadi semakin encer dan tinggi putih telur kental menurun. $\mathrm{CO} 2$ yang hilang melalui pori kerabang telur mengakibatkan konsentrasi ion bikarbonat dalam puth telur menurun dan merusak sistem buffer. Hal tersebut menjadikan $\mathrm{pH}$ telur naik dan putih telur bersifat basa yang diikuti dengan kerusakan serabut-serabut ovomucin. Hipotesis kerusakan membran vitelin pada penelitian ini yaitu telur kehilangan $\mathrm{CO} 2$ melalui pori kerabang sehingga $\mathrm{pH}$ telur meningkat. Peningkatan $\mathrm{pH}$ telur menyebabkan kerusakan pada serabut ovomucin. Kerusakan ovomucin akan meningkatkan jumlah air dalam putih telur. Semakin lama telur disimpan makan air yang berdifusi kedalam kuning telur semakin banyak sehingga menyebabkan keruskan membran vitelin dan penurunan indeks kuning telur (Jazil dkk., 2012). Ovomucin sangat berperan dalam pengikatan air untuk membentuk struktur gel albumen. Albumen akan semakin kental jika jala-jala ovomucin banyak dan kuat dengan viskosistas albumen tinggi. Protein albumen terdiri dari protein serabut yaitu ovomucin oleh karena itu semakin kental putih telur, maka semakin tinggi ovomucin dan fenomena ini mencerminkan semakin baik kualitas internal telur itik. Kenaikan nilai $\mathrm{pH}$ putih telur akan menyebabkan kerusakan fisikokimia serabutserabut ovomucin sehingga kekentalan putih telur akan menurun. Penurunan kekentalan putih telur dan elastisitas membran vitelin mengakibatkan kuning telur bergeser dari posisinya (Sukma, 2012).

P1 yaitu telur dengan perlakuan pencucian air dan perendaman ekstrak daun jambu biji yang disimpan selama 14 hari menunjukkan IKT yang tidak berbeda nyata dengan $\mathrm{P} 3, \mathrm{P} 5$ dan $\mathrm{P} 7$ namun berbeda nyata dengan P0, P2, P4, P6 dan P8. Hal ini menunjukkan bahwa perlakuan pencucian air dan perendaman ekstrak daun jambu biji tidak memberikan pengaruh nyata pada indeks kuning telur itik yang disimpan selama 14 hari. Hasil uji yang telah dilakukan menunjukkan kadar 
tanin ekstak daun jambu pada penelitian ini sebesar 3,9\%, diduga kadar tanin yang terdapat dalam ekstrak daun jambu kurang tinggi

untuk mempertahankan kualitas telur, sehingga tidak dapat mempertahankan IKT saat masa penyimpanan. Hal ini didukung oleh hasil penelitian yang dilakukan oleh Hadjrawati dkk. (2012), tentang pengaruh lama perendaman ekstrak kulit buah kakao dan lama penyimpanan terhadap daya awet telur ayam ras, mengungkapkan bahwa perendaman telur dalam ekstrak kulit buah kakao dengan kadar tanin 6,73\% selama 15 menit memiliki rata-rata indeks kuning telur terbaik pada penyimpanan 30 hari.

P3 yaitu telur yang dicuci dengan air dan disimpan selama 14 hari menunjukkan hasil yang tidak berbeda nyata dengan P1, P5 dan P7. Hasil juga menunjukkan perbedaan nyata antara P0, P2, P4, P6, dan P8. Perlakuan pencucian tidak memberikan pengaruh nyata terhadap nilai IKT yang disimpan selama 14 hari. Penurunan indeks kuning telur pada P3 disebabkan oleh waktu penyimpanan.

P4 dengan lama penyimpanan 28 hari menunjukkan IKT yang berbeda nyata dengan $\mathrm{P} 2$, P0, P1, P3, P5, dan P7, namun tidak berbeda nyata dengan P6 dan P8. Hasil tersebut dapat dilihat bahwa pada penyimpanan 28 hari, telur itik yang dicuci dengan air dan direndam menggunakan ekstrak daun jambu biji memiliki IKT yang lebih baik dari telur dengan perlakuan pencucian saja. Perlakuan pencucian telur dapat mempercepat penurunan kualitas telur karena pada saat telur dibersihkan pori kulit telur akan terbuka dan selaput kutikula yang melapisi kulit telur akan hilang. Jika selaput kutikula tidak ada, maka mikroorganisme akan masuk dengan mudah ke dalam telur (Fibrianti dkk., 2012). Kutikula merupakan lapisan paling luar dari kerabang telur yang tersusun dari $90 \%$ protein, $4 \%$ gula, 3\% lipida serta 3,5\% abu. Lapisan ini merupakan faktor pelindung pertama setelah telur dioviposisikan. Lapisan kutikula mudah hilang oleh pencucian sehingga efektivitasnya sangat terbatas dan hanya mampu bertahan 100 jam (Yuwanta, 2010), namun disisi lain pencucian berguna untuk menghilangkan kotoran yang menempel pada kerabang telur. Saraswati (2015) menyatakan bahwa penyimpanan telur dalam jangka waktu yang lama dibutuhkan kebersihan dari kerabang telur. Pencucian adalah salah satu cara untuk membersihkan kerabang telur. Pencucian telur dapat dilakukan asalkan tidak berlebihan.

P5 yaitu telur dengan perendaman ekstrak daun jambu biji dan disimpan selama 14 hari menunjukkan hasil yang berbeda nyata dengan $\mathrm{P} 0$, P2, P4, P6 dan P8 namun tidak berbeda nyata dengan perlakuan P1, P3, dan P7. Hasil perlakuan perendaman telur dan penyimpanan 28 hari pada P6 memiliki IKT yang berbeda nyata dengan P0, P1, P3, P5 dan P7 namun tidak berbeda nyata dengan $\mathrm{P} 2$, P4, dan $\mathrm{P} 8$. Hal ini menunjukkan bahwa perlakuan perendaman telur itik kedalam ekstrak daun jambu tidak memberikan pengaruh nyata pada penyimpanan 14 hari dan 28 hari karena tidak ada perbedaan nyata pada minggu pengamatan yang sama antara telur yang diberi perlakuan pencucian air, perendaman ekstrak daun jambu biji, serta telur dengan perlakuan pencucian dan perendaman ekstrak daun jambu biji. Faktor yang menyebabkan perbedaan nyata antara indeks kuning telur adalah waktu penyimpanan

Hasil analisis susut bobot telur itik dengan perlakuan pencucian air dan perendaman ektrak daun jambu biji (Psidium guajava) yang disimpan pada suhu ruang dengan lama penyimpanan yang berbeda menunjukkan nilai yang berbeda nyata $(\mathrm{P}<0,05) . \quad \mathrm{P} 0$ (telur itik berumur 1 hari) belum memiliki susut bobot telur, P7 yaitu telur dengan perlakuan penyimpanan 14 hari memiliki susut bobot telur sebesar 2,64\% dan P8 yaitu telur dengan perlakuan penyimpanan 28 hari memiliki susut bobot sebesar $5,16 \%$. P0 berbeda nyata dengan semua perlakuan P1, P2, P3, P4, P5, P6, P7 dan P8. Telur itik P7 memiliki susut bobot telur yang berbeda nyata dengan P0, P2, P4, P6, P8 dan berbeda tidak nyata dengan P1, P3, P5. Telur itik P8 memiliki susut bobot telur yang berbeda nyata dengan P0, P1, P3, P5, P7 dan berbeda tidak nyata dengan P2, P4, P6. Faktor yang mempengaruhi susut bobot telur itik pada penelitian ini adalah lama penyimpanan. Djaelani (2015) mengatakan terdapat pengaruh yang nyata antara susut bobot telur dengan penyimpanan selama 7, 14 dan 21 hari. Nilai kenaikan susut 
bobot telur berbanding lurus dengan lama penyimpanan. Semakin lama waktu penyimpanan semakin besar penyusutan bobot telur. Penyusutan bobot telur yang terjadi selama penyimpanan disebabkan oleh penguapan air dan pelepasan gas $\mathrm{CO} 2$ dari dalam telur melalui pori kerabang. Penguapan dan pelepasan gas ini terjadi secara terus menerus selama penyimpanan sehingga semakin lama telur disimpan berat telur akan semakin berkurang.

Menurut Sudaryani (2000) sejak telur dioviposisikan terjadi proses penguapan air dan pelepasan gas seperti $\mathrm{CO} 2, \mathrm{NH} 3, \mathrm{~N} 2$, dan sedikit $\mathrm{H} 2 \mathrm{~S}$ melalui pori kerabang telur sebagai hasil degradasi bahan-bahan organik. Proses ini berlangsung secara terus-menerus sehingga menyebabkan penurunan kualitas putih telur, terbentuknya rongga udara, dan menurunkan bobot telur. Saraswati (2015) menyatakan rata-rata produksi $\mathrm{CO} 2$ telur per hari sebesar $3,5 \mathrm{mg}$. Penguapan air melalui kerabang telur, difusi air dari putih telur ke kuning telur menyebabkan $\mathrm{pH}$ naik dan struktur gel puth telur rusak. Kejadian tersebut berlangsung terus menerus, sehingga semakin lama telur disimpan isi telur semakin encer. Susut bobot telur itik P1 yaitu telur itik dengan perlakuan pencucian air dan perendaman ekstrak daun jambu biji yang disimpan selama 14 hari menunjukkan angka yang tidak berbeda nyata dengan perlakuan P3, P5, dan P7, namun susut bobot P1 berbeda nyata dengan P0, P2, P4, P6 dan P8. Perlakuan yang sama dengan penyimpanan 28 hari pada P2 menunjukkan perbedaan nyata susut bobot antara perlakuan P2 dengan P0, P1, P3, P5 dan P7 dan perbedaan tidak nyata dengan $\mathrm{P} 4, \mathrm{P} 6$, dan $\mathrm{P} 8$. Susut bobot telur itik dengan perlakuan pencucian dan penyimpanan 14 hari pada $\mathrm{P} 3$ menunjukkan perbedaan nyata dengan P0, P2, P4, P6 dam P8, serta perbedaan tidak nyata dengan P1, P5 dan P7. Perlakuan yang sama yaitu pencucian telur itik pada P4 dengan penyimpanan 28 hari menunjukkan perbedaan nyata antara P0, P1, P3, P5 dan P7 dan perbedaan tidak nyata dengan $\mathrm{P} 2$, P6, dan P8. Susut bobot telur itik P5 dengan perlakuan perendaman ekstrak daun jambu biji dan penyimpanan 14 hari menunjukkan perbedaan nyata antara P0, P2, P4, P6 dam P8, serta perbedaan tidak nyata dengan P1, P5 dan P7.

P6 yaitu perlakuan perendaman dengan lama penyimpanan 28 hari menunjukkan hasil yang berbeda nyata dengan P0, P1, P3, P5 dan P7 serta terdapat perbedaan tidak nyata dengan $\mathrm{P} 2, \mathrm{P} 4$ dan P8. Hasil tersebut terlihat bahwa perlakuan pencucian air, perendaman ekstrak daun jambu biji serta perlakuan pencucian air dan perendaman telur itik ke dalam ekstak daun jambu biji (Psidium guajava) tidak berpengaruh nyata terhadap susut bobot telur itik, karena tidak ada perbedaan nyata antar perlakuan pada pengamatan di hari yang sama. Hal yang mempengaruhi penurunan susut bobot telur adalah lama penyimpanan. Perlakuan pencucian dan perendaman telur dalam ekstrak daun jambu biji tidak mampu untuk mempertahankan bobot telur itik pada hari ke 14 dan hari ke 28. Diduga kadar tanin yang digunakan dalam penelitian ini sebesar 3,9\% kurang tinggi untuk mempertahankan kualitas telur.

Suhu rata-rata ruangan selama penelitian adalah $27,56^{\circ} \mathrm{C}$ dengan kelembaban $71,58 \%$. Yuwanta (2010) menyatakan bahwa penurunan bobot telur selama penyimpanan dipengaruhi oleh suhu penyimpanan, kelembaban relatif dan porositas kerabang telur. Suhu dan kelembaban yang cukup tinggi selama penyimpanan menyebabkanpenurunan bobot telur semakin cepat. Penyimpanan pada suhu $25^{\circ} \mathrm{C}$ dengan kelembaban relatif $70 \%$ akan menyebabkan telur kehilangan bobot $0,8 \mathrm{~g} /$ minggu/butir dan pada suhu $30^{\circ} \mathrm{C}$ telur akan kehilangan bobot sebesar 2 g/minggu/butir. Apabila kelembaban relatif meningkat menjadi $80 \%$, maka penurunan berat air dalam telur bertambah sebesar $20 \mathrm{mg} /$ hari/butir.

\section{KESIMPULAN}

Perendaman telur itik ke dalam ekstrak daun jambu biji dengan kadar tanin 3,9\% selama 30 menit tidak efektif untuk mempertahankan kualitas telur ditinjau dari penurunan kadar lemak, kanaikan nilai susut bobot telur dan penurunan indeks kuning telur itik.

\section{DAFTAR PUSTAKA}


Alfiah, C., dan Wahono H.S. 2015 Penanganan Pasca Panen Kelapa Sawit (Penyemprotan $\mathrm{CaCl}_{2}$ Dan Kalium Sorbat Terhadap Mutu Crude Palm Oil). Jurnal Pangan dan Agroindustri 3(1) : 61-72

Asjayani, R. 2014. Aplikasi Ekstrak Daun Eceng Gondok (Eichornia crassipes) pada Level dan Lama Simpan terhadap Kualitas Telur Ayam Ras. Skripsi. Universitas Hasanuddin, Makassar.

Bintanah, S dan E. Handarsari. 2014. Komposisi Kimia dan Organoleptik Formula Nugget Berbasis Tepung Tempe dan Tepung Ricebran. Indonesian Journal of Human Nutrition 1(1): 57-70.

Birowo, J., I. M. Sukada dan, I. G. K. Suarjana. 2013. Perbandingan Jumlah Bakteri Coliform Pada Telur Ayam Buras Yang Dijual Di Pasar Bersanitasi Baik Dan Buruk. Indonesia Medicus Veterinus 2(3) : 269 280

Budisutiya, dan E. Arisandi 2006. Penggunaan Babakan Kulit Kayu Bakau (Rhizophora Mucronata Lamck) Sebagai Pengawet Telur Ayam Ras. Jurnal Hutan Tropis Borneo 18: 39-53.

Cornelia, A., I. K. Suada, dan M. D. Rudyanto. 2014. Perbedaan Daya Simpan Telur Ayam Ras yang Dicelupkan dan Tanpa Dicelupkan Larutan Kulit Manggis. Indonesia Medicus Veterinus 3(2): 112119

Danarto, Y. C., S. A. Prihananto dan Z. A. Pamungkas. 2011. Pemanfaatan Tanin dari Kulit Kayu Bakau sebagai Pengganti Gugus Fenol pada Resin Fenol Formaldehid. Prosiding Seminar Nasional Teknik Kimia "Kejuangan"

Djaelani, M.A. 2015. Pengaruh Pencelupan pada Air Mendidih dan Air Kapur Sebelum Penyimpanan Terhadap Kualitas Telur Ayam Ras 2017. Kualitas Telur Puyuh Jepang (Coturnix coturnix japonica L.) Berdasarkan Variabel pH Telur, Kandungan Protein Telur dan Indeks Puth Telur setelah dilakukan Pencucian dan disimpan Selama Waktu Tertentu. Buletin Anatomi dan Fisiologi 2(1) : 26-30
Fibrianti, S. M., I. K. Suada, dan M. D. Rudyanto. 2012. Kualitas Telur Ayam Konsumsi yang dibersihkan dan tanpa Dibersihkan Selama Penyimpanan Suhu Kamar . Indonesia Medicus Veterinus 1(3): 408- 416.

Geveke D.J., Gurtler J.B., Jones D.R. and Bigley A.B. 2016. Inactivation of Salmonella in Shell Eggs by Hot Water Immersion and Its Effect on Quality. J Food Sci. 81(3): 709-14.

Hadjrawati., J.C. Likadja dan Hessy. 2012. Pengaruh Lama Perendaman Ekstrak Kulit Buah Kakao dan Lama Penyimpanan terhadap Daya Awet Telur Ayam Ras. Agriplus 1(22).

Jazil, N. A. Hintono, dan S. Mulyani. 2012. Penurunan Kualitas Telur Ayam Ras dengan Intensitas Warna Coklat Kerabang Berbeda Selama Penyimpanan. Jurnal Aplikasi Teknologi Pangan 1(2): 43-47.

Kartasapoetra, G. 2006. Budidaya Tanaman Berkhasiat Obat. Penerbit Rineka Cipta, Jakarta

Ketaren, P. 2007. Peran Itik Sebagai Penghasil Telur dan Daging Nasional. Jurnal Wartazoa 17(3) : 117-127

Koswara, S. 2009. Teknologi Pengolahan Telur. eBookPangan.com.

Kurniawati, A. 2006. Formulasi Gel Antioksidan Ekstrak Daun Jambu Biii (Psidium guajava L) dengan Menggunakan Aquapec HV-505. Skripsi. Jurusan Farmasi FMIPA UNPAD.

Oematan, Z.Z.B. 2015. Pengaruh Perbedaan Suhu dan Waktu Ekstraksi Terhadap Kandungan Tanin Daun Jambu Mete (Anacardium occidentale L.). Jurnal Ilmiah Mahasiswa Universitas Surabaya 5(2).

Rasyaf, M. 2011. Pengelolaan Produksi Telur. Penerbit Kanisius, Jakarta.

Saraswati, T. R. 2015. Telur, Optimalisasi Fungsi Reproduksi Puyuh dan Biosintesis Kimiawi Bahan Pembentuk Telur. Lembaga Studi dan Konsultasi Farmakologi Indonesia, Depok. 
Sukardi., A. R. Mulyarto, dan W. Safera. 2007. Optimasi Waktu Ekstraksi terhadap Kandungan Tanin pada BubukEkstrak Daun Jambu Bïi serta Biaya Produksinya. Jurnal Teknologi Pertanian 2(8): 88-94.

Sukma, A.W., A. Hintono dan B.E.Setiani 2012. Perubahan Mutu Hedonik Telur Asin Sangrai Selama Penyimpanan. Animal Agriculture Journal 1(1)

Soeparno, R.A., I. Rihastuti dan S. Triatmojo. 2011. Dasar Teknologi Hasil Ternak. Gadjah Mada University.Yogyakarta.

Winamo, F.G. dan S. Koswara. 2002. Telur: Komposisi, Penanganan dan Pengolahannya, M-Brio Press, Bogor.

Yuwanta, T. 2010. Telur dan Kualitas Telur. Gadjah Mada University Press, Yogyakarta.

Zulfatunnisa, Agus S., dan Imam T. 2015. Pengaruh Penggunaan Telur Yang Diawetkan Dengan Parafin Dan Penggunaan Sodium Bikarbonat Terhadap Sifat-Sifat Fisikawi, Kimiawi Dan Organoleptik Kerupuk Telur. Jurnal Ilmu Dan Teknologi Hasil Ternak 10(1) :54-72 